\title{
NUP98 Gene Mutation
}

National Cancer Institute

\section{Source}

National Cancer Institute. NUP98 Gene Mutation. NCI Thesaurus. Code C153268.

A change in the nucleotide sequence of the NUP98 gene. 